\title{
Simulasi Gempa Bumi Kampus Aman Bencana Di Universitas Islam Negeri Ar-Raniry Banda Aceh
}

Erdi Surya, Armi, Ismawirna, Hambali, Yulsafli, Zainuddin, Erfinawati, Jalaluddin, Sri Ismulyati, Edi Azwar

Universitas Serambi Mekkah

Jalan Muhammadiyah, Desa Batoh, Kecamatan Lueng Bata, Kota Banda Aceh, Indonesia, 23445

Email. Suryaerdi14@yahoo.com

DOI : 10.32672/btm.v1i4.1727

\begin{abstract}
ABSTRAK
Negara indonesia merupakan salah satu negara yang berada di wilayah rawan terhadap bencana alam gempa karena letak geografisnya yang berada pada pertemuan tiga lempeng tektonik besar di dunia, yaitu lempeng Indo-Australia, lempeng Eurasia dan lempeng Pasifik. Kesiapsiagaan bangunan akan bahaya gempa sangat direkomendasikan untuk mengurangi risiko yang ditimbulkan oleh kejadian gempa bumi yang tidak dapat diprediksi. Tujuan penulisan ini adalah mengevaluasi kesiapsiagaan bangunan pada salah satu Gedung Universitas Islam Negeri Ar-Raniry Kecamatan Syiah Kuala Kota Banda Aceh terhadap bencana gempa dan memberikan pilihan tindakan bagi kampus dalam upaya meningkatkan parameter kesiapsiagaan (struktur dan non struktur ) serta memberikan gambaran umum dalam melakukan monitoring terhadap kampus dalam mencapai indicator kampus aman bencana. Metode dalam kegiatan simulasi ini adalah student centered learning dengan memberikan pemahaman kepada mahasiswa dan siswa (i) mengenai berbagai macam penyebab, jenis bencana gempa bumi, serta upaya apa yang dilakukan pada kondisi sebelum terjadinya bencana, saat terjsadinya bencana dan pasca bencana itu terjadi. Kegiatan ini berusaha untuk menggali pengalaman mahasiswa/i dan siswa (i) dalam menghadapi kesiapsiagaan bencana gempa bumi. Setelah itu dilakukan evaluasi berupa simulasi dan bentuk-bentuk scenario penyelamatan diri saat terjadinya bencana gempa bumi. Skenario ini dilakukan secara berulang-ulang sampai seluruh mahasiswa dan siswa (i) mampu dan biasa menerapkan kegiatan tersebut sesuai dengan instruksi yang diberikan oleh pihak yang terkait. Berdasarkan hasil akhir dari kegiatan ini dapat di ambil kesimpulan bahwa mahasiswa/i dan siswa (i) mampu mengimplementasikan pengetahuan, sikap, tanggap darurat mampu meningkatkan kapasitas dalam menghadapi bencana gempa bumi.

Kata Kunci : Simulasi, bencana, gempa bumi
\end{abstract}

\section{PENDAHULUAN}

Bencana yang terjadi di Indonesia telah banyak menimbulkan dampak yang cukup besar pada berbagai sector salah satu nya pada sector pendidikan. Di sector pendidikan, bencana dapat berdampak pada bangunan sekolah, kampus. Data Badan 
Erdi Surya, dkk.

Penanggulangan Bencana (BNPB) menunjukkan bahwa lebih dari 130.000 bangunan sekolah berpotensi terhantam bencana gempa bumi. Oleh karena itu upaya untuk meminimumkan risiko di sekolah dan kampus menjadi hal yang sama., salah satunya melalui peningkatan kesiapsiagaan, komunitas sekolah, diharapkan upaya kesiapsiagaan komunitas sekolah dapat mengurangi korban jiwa maupun kerugian akibat bencana.

Secara geografis, geologis, dan demografis di Indonesia menyebabkan negara ini dikenal sebagai laboratorium bencana. Sesuai dengan UU No. 24 tahun 2007 tentang penanggulangan bencana. Terdapat enam bencana yang paling mengancam daerahdaerah di Indonesia. Salah satu bencana itu, yakni gempa bumi.

Menurut hasil riset BNPB (2017) potensi jumlah jiwa terpapar risiko bencana, jumlah kerugian fisik, ekonomi, dan lingkungan di Indonesia memiliki kategori sedangtinggi. Potensi kerugian dan kerusakan fisik infrastruktur serta perekonomian bersumber dari gempa bumi, yaitu dengan jumlah kerugian sebanyak 648.874 triliun, sedangkan korban jiwa berjumlah 86 juta jiwa. Jumlah ini akan semakin bertambah jika tidak dilakukan upaya mitigasi di wilayah rawan bencana gempa bumi. Pengetahuan mengenai pengurangan risiko bencana secara khusus belum masuk ke dalam kurikulum pendidikan di Indonesia (Kemdikbud, 2013).

Salah satu upaya meningkatkan kesiapsiagaan menghadapi bencana adalah melalui peningkatan kapasitas sekolah. Peningkatan kesiapsiagaan kapasitas sekolah dapat dilakukan melalui peningkatan sumberdaya manusia dan peningkatan kesiapsiagaan dari komponen fisik seperti bangunan dan infrastruktur lainnya.

\section{Permasalahan dan Tujuan}

Dalam pengabdian ini kurangnya pemahaman mahasiswa/i dan siswa (i) dalam kesiapsiagaan terhadap bencana gempa bumi berpotensi tsunami di Universitas Islam Negeri Ar-raniry, Kecamatan Syiah Kuala, Kota Banda Aceh, bertempat di ruangan Tarbiyah. Simulasi Tsunami yang kami lakukan bermaksud dan bertujuan agar dapat menambah wawasan dan pengalaman bagi kami, bagaimana sebaiknya bertindak saat terjadi bencana masyarakat diberikan pemahaman dan pengalaman tentang perilaku bencana, jalur-jalur evakuasi, pola pikir dan tindakan yang perlu atau tidak perlu dilakukan saat terjadi bencana, memanfaatkan jalur-jalur evakuasi memanfaatkan sistem informasi yang telah dibuat sebelumya, dan paling penting adalah memutuskan tindakan yang harus diambil dalam waktu yang singkat itu dengan mental yang baik. Seperti yang terjadi pada bencana Tsunami yang terjadi di Aceh dari simulasi ini kami lebih waspada ketika bencana datang dan melakukan tindakan secara cepat.

Simulasi Gempa dan Tsunami yang kami lakukan bertujuan untuk menambah wawasan dan pengalaman bagi kita semua dan kita dapat belajar dari pengalaman gempa dan tsunami di Aceh 15 tahun lalu. Pemerintah membuat program gerakan untuk mengurangi resiko dan korban bencana dibeberapa daerah yang rawan bencana. Misalnya, di Kota Banda Aceh. Salah satu program yang dilakukan oleh BPBA adalah pembinaan kampus aman bencana di Universitas Islam Negeri Ar-raniry, kecamatan Syiah Kuala, Kota Banda Aceh, bertempat di ruangan Tarbiyah pada hari rabu dan kamis tanggal 27-28 November 2019. 
BAKTIMAS

Jurnal Pengabdian pada Masyarakat
Vol. 1, No. 4,

Desember 2019
eISSN 2685-113x

pISSN 2685-0303

Tujuan latihan kesiapsiagaan :.

a. Untuk meningkatkan kesiapsiagaan dalam menghadapi suatu bencana dan juga untuk melatih pemahaman tugas dan tanggung jawab dari masing-masing fungsi terhadap kondisi darurat yang dapat terjadi kapanpun dan dimanapun.

b. Mengkaji kemampuan peralatan penunjang komunikasi sistem peringatan dini, penunjang evakuasi, serta penunjang tanggap darurat.

c. Mengeathui kriteria dalam memilih kampus yang akan menjadi kampus aman bencana.

d. Memberikan gambaran umum dalam hal pemantauan/monitoring

\section{METODE PELAKSANAAN KEGIATAN}

Dalam kegiatan simulasi ini dilakukan selama 2 (dua) hari yaitu pada tanggal 27-28 November 2019, bertempat di Universitas Islam Negeri Ar-Raniry Kecamatan Syiah Kuala Kota Banda Aceh. Penanggung jawab kegiatan yaitu Kasi kesiapsiagaan BPBA Provinsi Aceh beserta anggotanya, beberapa orang Dosen Pendamping dari fakultas keguruan dan ilmu pendidikan Universitas Serambi mekkah, dan dosen dan mahasiswa dari kampus lain seperti kampus UIN Ar-Araniry Banda Aceh, Unsyiah Banda Aceh, UNMUHA Banda Aceh, Basarnas, BMKG, kapolsek setempat, dan, anggota TNI. Target pengabdian yaitu mahasiswa/i dan siswa (i) . Adapun kegiatankegiatan yang dilakukan yaitu sebagai berikut :

1) Survei lapangan

Survei lapangan dilakukan pada tanggal 27 November 2018 di Universitas Islam Negeri Ar-Raniry Kecamatan Syiah Kuala Kota Banda Aceh. Kegiatan yang dilakukan adalah meninjau lokasi yang akan digunakan sebagai tempat pelaksanaan sosialisasi dan simulasi. Tim juga melakukan koordinasi dengan pihak BPBA, tokoh mahasiswa/i dan siswa (i) mengenai waktu dan lokasi untuk kegiatan serta segala sesuatu yang berkaitan dengan surat-menyurat dan peralatan yang dibutuhkan selama kegiatan berlangsung.

2) Sosialisasasi tentang bencana gempa bumi

Sosialisasi bencana gempa bumi dilakukan terhadap mahasiswa/i dan siswa (i). Peserta sosialisasi yang telah dipilih diberikan pengetahuan/ pemahaman dalam rangka meningkatkan kapasitasnya dalam menghadapi bencana gempa bumi melalui sosialisasi dan simulasi gempa bumi berpotensi tsunami di kampus tersebut.

3) Simulasi bencana gempa bumi kampus aman bencana

Kegiatan simulasi bertujuan untuk mengajak mahasiswa/i dan siswa (i) agar terbawa dalam situasi ketika terjadi bencana gempa bumi. Simulasi ini dilaksanakan di Universitas Islam Negeri Ar-raniry, kecamatan Syiah Kuala, Kota Banda Aceh, bertempat di ruangan Tarbiyah. Skenario simulasi kejadian dilakukan pada waktu saat kegiatan pembelajaran berlangsung (situasi normal), tiba-tiba terjadi gempa bumi yang berkekuatan $8,1 \mathrm{SR}$, dan mahasiswadan siswa (i) dituntut untuk bereaksi sebagai mana sikap dan tindakannya dalam menghadapi situasi tersebut. Settingan ini dilakukan secara berulang-ulang sampai mahasiswa/i dan siswa (i) mampu memperagakan sesuai dengan instruksi yang sudah diberikan sebelumnya. 
Erdi Surya, dkk.

\section{HASIL DAN PEMBAHASAN}

\section{Sosialisasi Bencana Gempa Bumi}

Kegiatan ini berisi tentang sosialisasi mengenai bencana gempa bumi kepada mahasiswa/i dan siswa (i) dan juga kepada mahasiswa/i PGSD Serambi Mekkah yang berjumlah 51 orang (Tabel 2). Pada tahap awal, narasumber menggali informasi mengenai pengalaman dan pengetahuan mahasiswa/i dan siswa (i) terhadap bencana gempa bumi yang pernah dirasakan pada tahun 2004 yang getarannya dapat dirasakan didaerah tempat tinggalnya. Hal ini dilakukan untuk mengingatkan kembali terhadap dampak dan kondisi kegempaan yang pernah terjadi diwilayah mereka tersebut berdasarkan pengalaman hidupnya.

Dari hasil evaluasi yang telah dilakukan akibat gempa bumi pada tahun 2004 yang merupakan salah satu pengalaman yang sangat berharga yang gempa tersebut berpusat di kota Banda Aceh. dan sekitarnya mengalami dampak dan kepanikan terhadap warga kampus dan fasilitas yang dimiliki oleh mahasiswa/i dan siswa (i) tersebut sebagian besar mengalami rusak berat dan ringan bahkan banyak korban yang berjatuhan. UIN Ar-Raniry merupakan salah satu universitas yang terkena dampak yang sangat parah akibat gempa bumi. dan tsunami. Berdasarkan pengalaman tersebut, maka fasilitator langsung memberikan pemahaman mengenai ciri-ciri dan ancaman bencana alam yang salah satu menjadi penyebab bencana gempa bumi. Peserta dalam kegiatan simulasi tersebut terlihat sangat antusias dalam mendengarkan pengarahan serta disela-sela kegiatan tersebut juga dilakukan tanya jawab dan untuk melihat sejauh mana pemahaman dan wawasan serta ilmu pengetahuan mereka mengenai materi yang disajikan oleh fasilitator tersebut.

Sedangkan pada tahap ke 2 kedua dilanjutkan dengan mensosialisasikan rencana kesiapsiagaan. Menurut (Deny Haryati, 2006: 14) parameter kesiapsiagaan bencana meliputi pengetahuan meliputi pengetahuan dan sikap terhadap risiko bencana, kebijakan dan panduan, sistem peringatan dini rencana untuk keadaan darurat bencana, serta kemampuan untuk memobilisasi sumber daya. Sedangkan menurut (BNPB 2012: 29-35) parameter kesiapsiagaan bencana meliputi : (1) Pengetahuan, sikap dan tindakan (2) Kebijakan sekolah/ madrasah (3) Perencanaan kesiapsiagaan (4) Mobilisasi sumber daya.

Kesiapsiagaan merupakan perencanaan tindakan untuk merespon jika terjadi bencana alam. Parameter untuk melihat pelaksanaan kesiapsiagaan dalam kehidupan masyarakat melalui empat parameter, yaitu (1) pengetahuan dan sikap; (2) perencanaan kedaruratan ;(3) system peringatan dini; dan (4) mobilisasi sumber daya (MPBI, 2005).

Rencana kesiapsiagaan yang harus dilakukan oleh peserta yaitu dengan menyimpan 9 benda yang akan dibutuhkan saat bencana (BNPB, 2017). Benda-benda yang harus dipersiapkan yaitu:

1. Air minum untuk 2 hari

2. Makanan ringan

3. Obat P3K

4. Obat-obatan

5. Lampu senter

6. baterai 
BAKTIMAS

Jurnal Pengabdian pada Masyarakat
Vol. 1, No. 4,

Desember 2019
eISSN 2685-113x

pISSN 2685-0303

7. Radio

8. Pakaian, jaket

9. Pembersih higienis (tisu basah, perlengkapan mandi).

Seluruh Peralatan ini disimpan didalam tas yang sewaktu-waktu dapat diambil ketika bencana gempa bumi melanda. Peralatan yang berupa makanan dan minuman sudah habis masa nya hendaknya dalam 3 bulan diganti dengan yang baru. Semua mahasiswa/i dan siswa (i) dianjurkan untuk mempersiapkan peralatan tersebut. Kegiatan selanjutnya yaitu sosialisasi tentang mitigasi bencana gempa bumi.

Mitigasi Menurut UU No. 24 Tahun 2007 mitigasi adalah serangkaian upaya untuk mengurangi risiko bencana, baik melalui pembangunan fisik maupun penyadaran dan peningkatan kemampuan menghadapi ancaman bencana. Dalam mitigasi bencana perlu dilakukan adanya serangkaian tindakan yang dilakukan, terdiri dari tindakan sebelum bencana, saat bencana dan setelah selesainya bencana atau disebut juga dengan pasca bencana. Kegiatan sosialisasi ini ditutup dengan melakukan evaluasi melalui diskusi dan Tanya jawab dengan peserta untuk meninjau tingkat pemahaman siswa terhadap materi sosialisasi.

\section{Simulasi Bencana Gempa Bumi}

Dalam pelaksanaan simulasi ini tentu adanya gambaran umum simulasi kesiagaan yaitu Mahasiswa/i dan siswa (i) memasuki lapangan gedung untuk melaksanakan apel bersama anggota BPBA, BMKG, RAPI, kapolsek, anggota TNI, beserta Dosen Pendamping masing-masing universitas. Saat melakukan apel ketua BPBA memberikan arahan tentang pelaksanaan simulasi pada kegiatan yang akan kami lakukan, setelah apel selesai barisan di bubarkan, panitia membagi beberapa regu yang diketuai oleh ketua tim sambil memberikan arahan.

\section{Managemen kesiagaan bencana}

Secara umum, kegiatan latihan kesiapsiagaan dibagi menjadi 4 (empat) tahapan utama, yakni tahap perencanaan, persiapan, pelaksanaan, dan evaluasi rencana perbaikan.

a) Tahap Perencanaan

Membentuk Tim Perencana :

- Bentuk organisasi latihan kesiapsiagaan agar pelaksaaan evakuasi berjalan dengan baik dan teratur.

- Tim Perencana terdiri dari pengarah, penanggung jawab, bidang perencanaan yang ketika pelaksanaan tim perencana berperan sebagai tim pengendali. Fungsi masingmasing, yakni :

Pengarah, bertanggung jawab memberi masukan yang bersifat kebijakan untuk penyelenggaraan latihan kesiapsiagaan, dan dapat memberikan masukan yang bersifat teknis dan operasional, mengadakan koordinasi, serta menunjuk penanggung jawab organisasi latihan kesiapsiagaan.

Penanggung Jawab, membantu pengarah dengan memberikan masukan-masukan yang bersifat kebijakan, teknis, dan operasional dalam penyelenggaraan latihan kesiapsiagaan.

Bidang Perencanaan/Pengendali, merencanakan latihan kesiapsiagaan secara menyeluruh, sekaligus menjadi pengendali ketika latihan dilaksanakan. 
Erdi Surya, dkk.

Bidang Opersional Latihan menjalankan perannya saat latihan. Yang terdiri dari Peringatan Dini, Pertolongan Pertama, Evakuasi dan Penyelamatan, Logistik serta Keamanan turut diuji dalam setiap latihan.

Bidang Evaluasi, mengevaluasi latihan kesiapsiagaan yang digunakan untuk perbaikan latihan ke depannya.

- Jumlah anggota tergantung tingkat kompleksitas latihan yang dirancang.

- Anggota organisasi bertanggung jawab pada perencanaan, pelaksanaan, hingga akhir latihan.

- Tugas dari tim perencana ini meliputi:

a. Menentukan risiko/ancaman yang akan disimulasikan.

b. Menentukan scenario bencana yang akan disimulasikan.

c. Merumuskan strategi pelaksanaan latihan kesiapsiagaan.

d. Menyiapkan kerangka kegiatan simulasi kesiapsiagaan (tipe simulasi, maksud, tujuan dan ruang lingkup latihan).

e. Mengintegrasikan kegiatan simulasi kesiapsiagaan menjadi kegiatan rutin dalam jangka panjang.

f. Menetapkan jadwal kegiatan latihan kesiapsiagaan.

g. Mendukung persiapan, pelaksana, dan evaluasi latihan.

h. Menyiapkan Rencana Tindak Lanjut setelah pelaksanaan kegiatan latihan kesiapsiagaan.

b) Menyusun Rencana Latihan Kesiapsiagaan

Menyusun rencana latihan kesiapsiagaan (aktivasi sirine dan evakuasi mandiri) yang melibatkan populasi di lingkungan tempat tinggal, kantor, sekolah, area publik, dan lain-lain. Rencana latihan tersebut berisi :

- Tujuan, sasaran, dan waktu pelaksanaan latihan kesiapsiagaan.

- Jenis ancaman yang dipilih atau disepakati untuk latihan kesiapsiagaan. Sebaiknya, latihan disesuaikan dengan ancaman di wilayah masing-masing.

- Membuat skenario latihan kesiapsiagaan. Skenario adalah acuan jalan cerita kejadian yang dipakai untuk keperluan latihan. Skenario dibuat berdasarkan kejadian yang paling mungkin terjadi di kampus. Skenario perlu dipahami oleh pelaksana dan peserta yang terlibat dalam latihan (contoh terlampir).

- Menyiapkan atau mengkaji ulang SOP/Protap yang sudah ada yaitu memastikan kembali :

Memastikan beberapa area/tempat alternatif yang akan dijadikan sebagai pusat evakuasi, tempat pengungsian maupun tempat perlindungan sementara. Tempat tersebut bisa memanfaatkan bangunan, seperti kantor, sekolah, tempat ibadah, gedung, dan area terbuka lainnya berdasarkan keamanan, aksesibilitas, juga lingkungan lokasi.

- Menentukan tempat pengungsian yang dipilih setelah mempertimbangkan kapasitas ketersediaan logistik (seperti makanan atau minuman, pakaian, obat-obatan dan peralatan medis, keperluan tidur, peralatan kebersihan, bahan bakar, dan lain-lain), serta ketersediaan fasilitas umum.

- Menetapkan dan menyiapkan jalur evakuasi.

- Orientasi sebelum latihan. 
BAKTIMAS

Jurnal Pengabdian pada Masyarakat
Vol. 1, No. 4,

Desember 2019
eISSN 2685-113x

pISSN 2685-0303

- Perencanaan Dokumentasi, dokumentasi diperlukan sebagai salah satu alat untuk pelaporan maupun monitoring dan evaluasi.

b) Tahap Persiapan

Hal-hal yang perlu dipersiapkan adalah :

- Briefing-briefing untuk mematangkan perencanaan latihan.

- Memberikan surat edaran kepada peserta yang terlibat simulasi.

- Menyiapkan gedung dan beberapa peralatan untuk keselamatan peserta simulasi.

- Memasang jalur evakuasi yang mudah dilihat semua orang.

c) Tahap Pelaksanaan

Berikut hal-hal yang perlu diperhatikan saat latihan simulasi berlangsung :

1. Tanda peringatan:

- Tanda bunyi latihan dimulai.

- Tanda evakuasi.

- Tanda latihan berakhir.

2. Reaksi Terhadap Peringatan

Latihan ini bertujuan untuk menguji reaksi peserta simulasi terhadap prosedur yang telah ditetapkan.

3. Dokumentasi

Rekaman dokumentasi diperlukan untuk melihat hal-hal yang masih perlu diperbaiki.

d) Tahap Evaluasi dan Rencana Perbaikan

1. Tahap Evaluasi

Tahapan evaluasi pasca bencana antara lain :

o Evaluasi penanganan jumlah korban jiwa yang selamat, luka-luka, hilang dan meninggal.

- Evaluasi tingkat kerusakan yang terjadi akibat bencana.

○ Evaluasi tingkat kerugian di bidang ekonomi, bagunan, dan lingkungan.

2. Rencana Perbaikan

Rencana perbaikan pasca bencana antara lain : Perbaikan dilingkungan kampus yang terkena bencana. Contohnnya: gedung, peralatan belajar dan mengajar.

3. Pemulihan sosial psikologis.

4. Pelayanan kesehatan.

\section{PENUTUP}

Simpulan:

a) simulasi kampus aman bencana bencana gempa bumi melalui penerapan sikap kesiapsiagaan dalam setiap diri mampu diaplikasikan dalam kehidupan sehari-hari.

b) Sebagian kecil dari peserta kampus aman bencana masih belum serius dalam melaksanakan simulasi gempa bumi.

c) lokasi disekitar ruangan Tarbiyah Universitas Islam Negeri Ar-raniry, dapat dimanfaatkan sebagai tempat evakuasi peserta simulasi kampus aman bencana 
Erdi Surya, dkk.

\section{DAFTAR PUSTAKA}

Badan Nasional Penanggulangan Bencana. 2012. Peraturan Kepala BNPB No. 02 tahun 2012 Tentang Pedoman Umum Pengkajian Risiko Bencana. Jakarta

BNPB. 2017. Buku Pedoman Latihan Kesiapsiagaan Bencana. Membangun Kesadaran, Kewaspadaan dan Kesiapsiagaan Dalam Menghadapi Bencana. Jakarta: Direktorat Kesiapsiagaan Badan Nasional Pencegahan dan Kesiapsiagaan Badan Nasional Penanggulangan Bencana. Jakarta: Direktorat Kesiapsiagaan Badan Nasional Pencegahan dan Kesiapsiagaan Badan Nasional Penanggulangan Bencana

BNPB. 2017. Buku Saku Tanggap Tangkas Tangguh Menghadapi Bencana Edisi 2017. Jakarta: Badan Nasional Penanggulangan Bencana.

Hidayanti, Deny, dkk. 2006. Kajian Kesiapsiagaan Masyarakat dalam Mengatasi Bencana Gempa Bumi dan Tsunami. Jakarta: LIPI Unesco

Kemendikbud. 2013. Kerangka Dasar Kurikulum 2013. Kementerian Pendidikan dan Kebudayaan Direktorat Jenderal Pendidikan Dasar. Jakarta

Masyarakat Penanggulangan Bencana Indonesia (MPBI). 2005. Membangun Ketahanan Bangsa dan Komunitas Terhadap Bencana. Jakarta.

Undang-Undang Nomor 24 Tahun 2007 tentang Penanggulangan Bencana 